\title{
Purification, Characterization, and a Potential Application of $\beta$-Glucosidase from Aspergillus pulverulentus YM-80
}

(Received January 8, 2004 ; Accepted April 7, 2004)

Tamio Mase, ${ }^{*}$ Shigeharu Mori and Masaaki Yokoe

Gifu Research and Development Center of Amano Enzyme Inc. (4-179-35, Sue-cho, Kakamigahara, Gifu 509-0108, Japan)

\begin{abstract}
A fungus, strain YM-80, isolated from a soil sample produced $\beta$-glucosidase ( $\beta$-D-glucoside glucohydrolase EC 3.2.1.21) in solid culture. The fungus was identified as Aspergillus pulverulentus from its taxonomical characteristics. The $\beta$-glucosidase was purified 18-fold from the culture extract by $\left(\mathrm{NH}_{4}\right)_{2} \mathrm{SO}_{4} \mathrm{pre}$ cipitation, DEAE-Toyopearl 650M, Butyl-Toyopearl 650M and Sephacryl S-200 chromatography. The purified enzyme appeared as a single band on SDS-PAGE. The molecular weight of the purified enzyme was estimated to be 118,000 by SDS-PAGE and 240,000 by gel filtration. The enzyme was an acidic protein with a pI of 4.5 and the specific activity was $308 \mathrm{U} / \mathrm{mg}$ protein. The optimum temperature and $\mathrm{pH}$ for the enzyme activity were $60^{\circ} \mathrm{C}$ and 4.0, respectively. This enzyme was stable in the $\mathrm{pH}$ range $3.0-7.0$ and also up to $50^{\circ} \mathrm{C}$. The activity of the enzyme was completely inhibited by $\mathrm{Hg}^{2+}$ and SDS. The purified enzyme was active with a broad range of $\beta$-linked glucosides but not $\alpha$-linked saccharides. Added during tofu processing, the enzyme was useful for the preparation of aglycon isoflavone-enriched tofu by hydrolysis of the glucoside form. However, isoflavones with $6 "-O$-acetyl and $6 "$ " $O$-malonyl glucosides were not converted into the aglycon form.
\end{abstract}

Key words: $\beta$-glucosidase, Aspergillus, solid culture, isoflavone, tofu

By definition, $\beta$-glucosidase (EC 3.2.1.21; $\beta$-D-glucoside glucohydrolase) hydrolyzes compounds containing $\beta$ glucosidic linkages by splitting off the terminal nonreducing $\beta$-D-glucose residues with release of $\beta$-Dglucose. ${ }^{1)}$ Many studies of $\beta$-glucosidases have been reported, because of their wide distribution in nature and their usefulness for food processing. A $\beta$-glucosidase with wide substrate specificity can catalyze the hydrolysis of not only $\beta$-oligoglucosides but also aryl and alkyl $\beta$ glucosides. ${ }^{2)}$ In plants used as food, the glycosides of various flavones and anthocyanins are pigments that contain a sugar residue and a non-sugar portion termed the aglycon, which is often a phenolic derivative. ${ }^{3)}$ For example, the $\beta$ glucosidases contribute to the formation of flavor, color and anti-oxidants originating in their aglycon in fermentation-produced food such as wine ${ }^{4)}$ or in the food industries such as tea." The bioavailability of these phenolic compounds converted into aglycon form is enhanced and contributes to human health.

$\beta$-Glucosidases from fungi such as Aspergillus niger, ${ }^{6}$ Thermomyces langinosus, ${ }^{7)}$ Cladosporium resinae ${ }^{8)}$ and Acremonium persicinum ${ }^{9}$ have been reported (especially Aspergillus species) to be good sources of $\beta$-glucosidase. The $\beta$-glucosidase from A. niger,${ }^{10)}$ A. oryzae, ${ }^{11)} A$. fumigatus $^{12)}$ and $A$. sojae $^{13)}$ have been purified and their characteristics recorded. Above all, black Aspergillus species are one of the best producers of food processing enzymes recognized as food additives, both from the standpoint of historical results and non-pathogenicity. We searched for a $\beta$-glucosidase-producing black Aspergillus with wide substrate specificity toward phenolic compounds with a $\beta$-glucoside form for use as a food additive during food

* Corresponding author (Tel. +81-583-79-1220, Fax. +81-583-

79-1232, E-mail: tmase@amano-enzyme.ne.jp) processing. Our screening discovered Aspergillus pulverulentus YM-80, which had been isolated from a soil sample and was found to be very suitable for this purpose.

In this paper we report the purification of $\beta$-glucosidase from a solid culture and the general characteristics such as molecular weight, optimum $\mathrm{pH}$ and potential application.

\section{MATERIALS AND METHODS}

Chemicals. $\quad$-Nitrophenyl monosaccharide, glycosides, sophorose, and laminaribiose were purchased from Sigma Chemical Co. Cellooligosaccharides were obtained from Wako Pure Chemical Industries, Ltd. All other chemicals were of analytical grade.

Microorganisms. The strain YM-80, isolated from soil in Japan, was used in this study. Strain YM-80 was identified taxonomically as Aspergillus pulverulentus based on the procedures of K.B. Raper. ${ }^{14)}$ The culture was maintained on potato dextrose agar slants.

Cultivation. An aliquot containing hyphae grown on slants was inoculated into $100 \mathrm{~mL}$ of culture solution containing $10 \%(\mathrm{w} / \mathrm{v})$ commercial wheat bran. After incubation at $30^{\circ} \mathrm{C}$ for $40 \mathrm{~h}$, the culture broth was used as a subculture. One liter Erlenmeyer flasks with cotton stoppers were charged with $360 \mathrm{~g}$ of medium prepared by thoroughly mixing $1000 \mathrm{~g}$ wheat bran with $800 \mathrm{~mL}$ of tap water, then sterilized at $121^{\circ} \mathrm{C}$ for $45 \mathrm{~min}$. After cooling, the flasks were inoculated with $40 \mathrm{~mL}$ of subculture. The contents were mixed thoroughly and incubated at $29^{\circ} \mathrm{C}$ for 4 days.

Purification of a $\beta$-glucosidase. All operations were performed at $5^{\circ} \mathrm{C}$.

Step 1. Ammonium sulfate fractionation. About 840 $\mathrm{g}$ of the solid culture of $A$. pulverulentus YM-80 grown 
on wheat bran at $29^{\circ} \mathrm{C}$ for 4 days was immersed in about $4000 \mathrm{~mL}$ of distilled water for $16 \mathrm{~h}$. After filtration with filter paper, the filtrate was concentrated to $300 \mathrm{~mL}$ by ultrafiltration using AIV-1010 (Asahi Kasei Co.) with 100\% recovery of $\beta$-glucosidase activity. The enzyme solution $(300 \mathrm{~mL})$ was re-filtered to remove insolubles. To 275 $\mathrm{mL}$ of the filtrate, solid $\left(\mathrm{NH}_{4}\right)_{2} \mathrm{SO}_{4}$ was added up to $70 \%$ saturation with stirring and left overnight at $5^{\circ} \mathrm{C}$. The resulting precipitates were collected by filtration, and dissolved in $90 \mathrm{~mL}$ of $50 \mathrm{~mm}$ Tris- $\mathrm{HCl}$ buffer ( $\mathrm{pH} \mathrm{8.5).} \mathrm{The}$ enzyme solution was dialyzed against $50 \mathrm{~mm}$ Tris- $\mathrm{HCl}$ buffer ( $\mathrm{pH} 8.5)$.

Step 2. DEAE-Toyopearl 650M column chromatography. The enzyme solution in step 1 was applied to a DEAE-Toyopearl $650 \mathrm{M}$ column $(4 \phi \times 20 \mathrm{~cm})$ equilibrated with $50 \mathrm{~mm}$ Tris- $\mathrm{HCl}$ buffer $(\mathrm{pH} 8.5)$ at a flow rate of $6 \mathrm{~mL} / \mathrm{min}$. After the column was washed with 50 $\mathrm{mL}$ of equilibration buffer, the adsorbed enzyme was eluted with $500 \mathrm{~mL}$ of a linear gradient of $0-0.3 \mathrm{M} \mathrm{NaCl}$ in the same buffer. Protein with enzymatic activity was eluted with $0.15 \mathrm{M} \mathrm{NaCl}$ in the buffer and the active fraction pooled was equilibrated with $50 \mathrm{~mL}$ Tris- $\mathrm{HCl}$ buffer (pH 7.0) containing $2 \mathrm{M}\left(\mathrm{NH}_{4}\right)_{2} \mathrm{SO}_{4}$ by dialysis against the same buffer.

Step 3. Butyl-Toyopearl 650M column chromatography. The enzyme solution in step 2 was applied to Butyl-Toyopearl $650 \mathrm{M}$ column $(3 \phi \times 10 \mathrm{~cm})$ equilibrated with the same buffer with $2 \mathrm{M}\left(\mathrm{NH}_{4}\right)_{2} \mathrm{SO}_{4}$. After the column was washed with $50 \mathrm{~mL}$ of equilibration buffer, the adsorbed enzyme was eluted with $150 \mathrm{~mL}$ of a linear gradient of $2-0 \mathrm{M}\left(\mathrm{NH}_{4}\right)_{2} \mathrm{SO}_{4}$ in the same buffer. The active fractions eluted with $1 \mathrm{M}\left(\mathrm{NH}_{4}\right)_{2} \mathrm{SO}_{4}$ were pooled and dialyzed against $50 \mathrm{~mm}$ Tris- $\mathrm{HCl}$ buffer $(\mathrm{pH} 7.0)$ with $0.5 \mathrm{M}$ $\mathrm{NaCl}$.

Step 4. Sephacryl S-200 column chromatography.

Four $\mathrm{mL}$ of enzyme solution obtained from step 3 was subjected to gel filtration on a Sephacryl S-200 column $(3.5 \phi \times 100 \mathrm{~cm})$ using the same buffer at a flow rate of $20 \mathrm{~mL} / \mathrm{h}$. After the active fractions were collected and concentrated with ultrafiltration, the purified enzyme solution was dialyzed against $50 \mathrm{mM}$ McIlvain buffer ( $\mathrm{pH} 4.0$ ) and stored at $4{ }^{\circ} \mathrm{C}$.

Enzyme assay. The standard assay mixture for $\beta$ glucosidase activity contained $0.5 \mathrm{~mL}$ of $10 \mathrm{mM} p$ nitrophenyl $\beta$-D-glucoside ( $p$ NPG), $0.4 \mathrm{~mL}$ of $50 \mathrm{~mm}$ McIlvain buffer ( $\mathrm{pH} 4.0)$ and $0.1 \mathrm{~mL}(0.007-0.035 \mathrm{U})$ of enzyme solution. After incubation for $15 \mathrm{~min}$ at $50^{\circ} \mathrm{C}, 4$ $\mathrm{mL}$ of $0.1 \mathrm{M} \mathrm{NaHCO}_{3}$ was added to the reaction mixture. $p$-Nitrophenol liberated was estimated by measuring the absorbance of the mixture at $420 \mathrm{~nm}$. One unit of enzyme activity was defined as the amount of enzyme that catalyzed the liberation of $1.0 \mu \mathrm{mol}$ of $p$-nitrophenol $/ \mathrm{min}$ under the standard assay conditions.

Protein assay. The protein concentration was measured with Bio-Rad protein reagent (Bio-Rad Laboratories, Richmond, CA, USA) using bovine serum albumin as the standard. The absorbance at $280 \mathrm{~nm}$ was used for monitoring protein in column effluent.

Electrophoresis. SDS-PAGE was done with the Phast System (Pharmacia Biotech Co., Ltd.) using a Phast Gel Homogeneous 7.5 (Pharmacia Biotech Co., Ltd.). Protein markers $M r$ 30,000-205,000 (Amersham Biosciences K. $\mathrm{K}$. Tokyo, Japan) and $1 \mu \mathrm{L}$ of SDS-treated enzyme solution $(20 \mu \mathrm{g} / \mathrm{mL})$ were used for the molecular weight calibration. Protein was stained with Coomassie Brilliant Blue $\mathrm{R}-250$. The $\mathrm{p} I$ of the purified enzyme was measured using an LKB Ampholine electrofocusing apparatus (110 $\mathrm{mL}$ ), by the method of Vesterberg and Svensson at $500 \mathrm{~V}$ and $4{ }^{\circ} \mathrm{C}$ for $48 \mathrm{~h}^{15)}$ The ampholite concentration was $1 \%$ with a $\mathrm{pH}$ range of 3-6 in a sucrose gradient and $5 \mathrm{mg}$ of enzyme protein was applied.

Gel filtration for molecular weight determination. The molecular weight was also estimated by gel filtration. with a Sephadex G-200 column $(2 \phi \times 95 \mathrm{~cm})$. After equilibration with $50 \mathrm{mM}$ Tris- $\mathrm{HCl}$ buffer $(\mathrm{pH}$ 7.0) with $0.5 \mathrm{M} \mathrm{NaCl}, 1 \mathrm{~mL}$ of the purified enzyme $(350 \mathrm{U} / \mathrm{mL})$ was applied to the column. The flow rate was $10 \mathrm{~mL} / \mathrm{h}$, and $2.5 \mathrm{~mL}$ fractions were collected.

Measurement of sugar content. The sugar content in the purified enzyme (100 $\mu \mathrm{g}$ of protein) was measured by the phenol-sulfuric acid method as glucose equivalents. ${ }^{16)}$

Preparation of tofu enriched isoflavone aglycon form. One hundred grams of commercial soybean was soaked in $600 \mathrm{~mL}$ of tap water at $10^{\circ} \mathrm{C}$ for $15 \mathrm{~h}$, and ground with a homogenizer (Nihon Seiki Co). Purified $\beta$-glucosidase $(100 \mathrm{U})$ was added to the ground soybean suspension and incubated at $50^{\circ} \mathrm{C}$ for $1 \mathrm{~h}$. The resulting suspension was heated to boiling for $4 \mathrm{~min}$ and filtered through cotton cloth to separate soybean milk. The coagulant (2 $\mathrm{g}$ of $\mathrm{CaSO}_{4}$ ) was added to the soymilk and mixed. After discarding the supernatant (whey), the white coagulated mass was transferred to a box with cloth inside and pressed to remove excess whey. The mass was taken out and the content of isoflavone was measured with HPLC based on Toda's method. ${ }^{17)}$

\section{RESULTS}

\section{Identification of an isolated fungus.}

The morphological characteristics of the fungus strain YM-80 are shown in Table 1. Culture tests were done by the procedures of K.B. Raper ${ }^{14)}$ by using Czapeck-Dox agar and Malt extract agar as test media. The color of its conidial heads was brownish-black to black. The surfaces of conidia were rough-wall and conidiogenous cells were biseriate. Conidiophores were $6^{-8} \mathrm{~mm}$ in length. On comparing these characteristics with the literature, the fungus strain YM-80 was identified as Aspergillus pulverulentus. The fungus strain YM-80 has been deposited at the Fermentation Research Institute, Japan, as FERM P-15340.

\section{Purification of the enzyme.}

The enzyme was purified by $\left(\mathrm{NH}_{4}\right)_{2} \mathrm{SO}_{4}$ fractionation and consecutive column chromatography. A summary of the purification is presented in Table 2. A minor active fraction, about $4 \%$ of the total activity, was removed with Butyl-Toyopearl column chromatography. The final recovery of enzyme activity was $15 \%$ and the specific activity increased 18-fold against the concentrated extract from solid culture. The purified enzyme was used for subsequent characterization. 
Table 1. Morphological characteristics of Aspergillus pulverulentus YM-80.

Cultural characteristics

\begin{tabular}{lcc}
\hline Characteristics & Czapek agar & Malt extract agar \\
\hline $\begin{array}{l}\text { Growth rate } \\
\text { Conidiogenesis } \\
\text { Colony color }\end{array}$ & $\begin{array}{c}\text { Rather restricted } \\
\text { Good }\end{array}$ & $\begin{array}{c}\text { Fairly rapid } \\
\text { Good }\end{array}$ \\
& Conidial areas black & $\begin{array}{c}\text { Conidial areas } \\
\text { brownish black }\end{array}$ \\
Surface texture & Mycelium white & Mycelium white \\
Reverse & White & High, flocculent \\
\hline Microscopic characteristics (grown on Czapek agar)
\end{tabular}

Table 2. Purification of $\beta$-glucosidase from Aspergillus pulverulentus YM-80.

\begin{tabular}{lcccc}
\hline \multicolumn{1}{c}{ Purification step } & $\begin{array}{c}\text { Total } \\
\text { protein } \\
(\mathrm{mg})\end{array}$ & $\begin{array}{c}\text { Total } \\
\text { activity } \\
(\mathrm{U})\end{array}$ & $\begin{array}{c}\text { Specific } \\
\text { activity } \\
(\mathrm{U} / \mathrm{mg})\end{array}$ & $\begin{array}{c}\text { Recovery } \\
(\%)\end{array}$ \\
\hline Culture filtrate & 3110 & 53100 & 17.1 & 100 \\
Ammonium sulfate & 1150 & 40800 & 35.5 & 77 \\
DEAE-Toyopearl 650M & 198 & 24400 & 123 & 46 \\
Butyl-Toyopearl 650M & 55.5 & 12200 & 220 & 23 \\
Sephacryl S-200 & 25.9 & 7970 & 308 & 15 \\
\hline
\end{tabular}

The enzyme activities were measured by the standard assay method with $p$ NP $\beta$-glucoside.

\section{Properties of the purified enzyme.}

The purified enzyme gave a single band corresponding to a molecular weight of about 118,000 on SDS-PAGE (Fig. 1) and 240,000 by gel filtration (Fig. 2). The purified enzyme was tested with isoelectric focusing to find the isoelectric point and also to check its homogeneity. The enzyme was judged to be homogeneous and the $\mathrm{p} I$ value was 4.5 . The sugar content of the purified enzyme was $28.1 \%$ (data not shown).

\section{Effect of $\mathrm{pH}$ and temperature on the activity of the enzyme.}

The effect of $\mathrm{pH}$ and temperature on the activity of the purified enzyme $(0.015 \mathrm{U})$ was studied under the standard assay conditions. The purified enzyme showed maximum activity at $\mathrm{pH} 4.0$ (Fig. 3A) and at $60^{\circ} \mathrm{C}$ (Fig. 3B).

\section{Stabilities of the enzyme toward $\mathrm{pH}$ and temperature.}

Enzyme stability at different $\mathrm{pH}$ levels was measured by incubating the enzyme solution $(3 \mathrm{U} / \mathrm{mL})$ at $40^{\circ} \mathrm{C}$ and different values of $\mathrm{pH}$ for $60 \mathrm{~min}$. After cooling in an ice bath and 20-fold dilution with $50 \mathrm{mM}$ McIlvain buffer

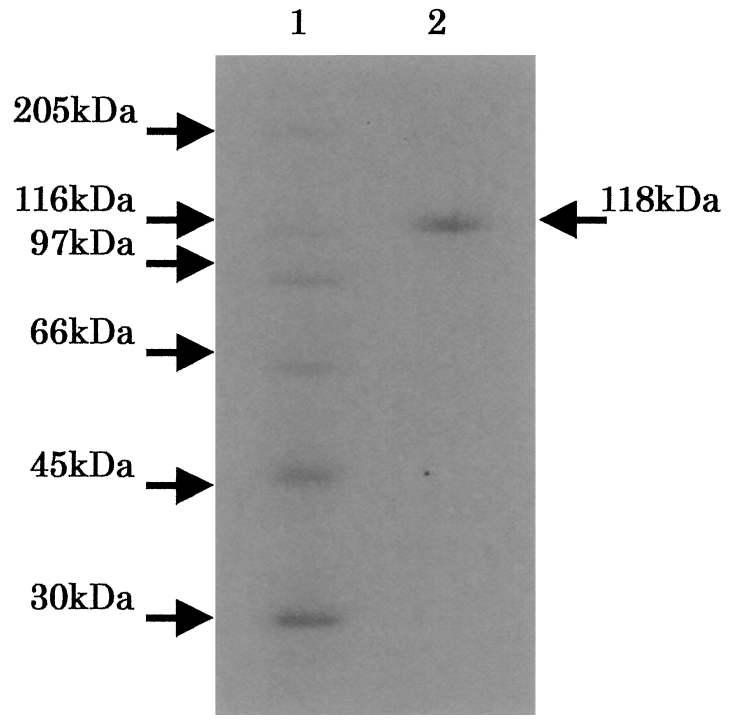

Fig. 1. SDS-PAGE of the purified $\beta$-glucosidase.

Lanes 1 and 2 indicate standard proteins and the enzyme, respectively. Standard marker proteins: myosin rabbit muscle $(205,000)$; $\beta$-galactosidase E. coli $(116,000)$; phosphorylase rabbit muscle $(97,000)$; bovine serum albumin $(66,000)$; ovalbumin chicken egg $(45,000)$; carbonic anhydrase bovine erythrocyte $(30,000)$ as a standard.

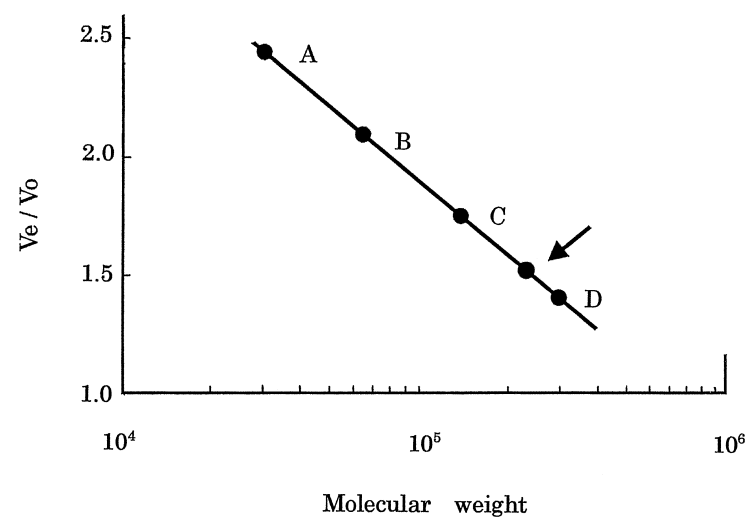

Fig. 2. Determination of molecular weight of $\beta$-glucosidase by Sephadex G-200 gel filtration.

A, myokinase yeast $(32,400)$; B, enolase yeast $(67,000)$; $C$, lactic dehydrogenase pig heart $(142,000) ; \mathrm{D}$, glutamate dehydrogenase yeast $(290,000)$ as a standard. Arrow indicates eluting position of $\beta$-glucosidase.
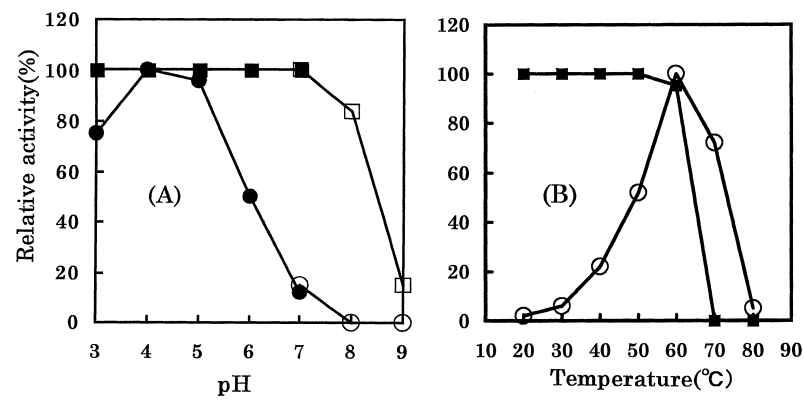

Fig. 3. Optimum $\mathrm{pH}$ and $\mathrm{pH}$ stability (A), and optimum temperature and thermal stability (B) of the purified $\beta$-glucosidase.

(A) Optimum $\mathrm{pH}(\boldsymbol{\bullet}, \bigcirc)$ and $\mathrm{pH}$ stability $(\boldsymbol{\square}, \square)$ after incubation at $40^{\circ} \mathrm{C}$ for $60 \mathrm{~min}$ were measured by the standard assay method. Buffer systems used were McIlvain buffer, $\mathrm{pH}$ 3.0-7.0 ( 口); $50 \mathrm{~mm}$ Tris-HCl buffer, pH 7.0-9.0 $(\bigcirc, \square)$. (B) Optimum temperature $(\bigcirc)$ at $\mathrm{pH} 4.0$ and thermal stability $(\square)$ after incubation at pH 4.0 for 10 min were measured by the standard assay method. 
(pH 4.0), the residual activity was measured under the standard assay conditions with $0.015 \mathrm{U}$ of enzyme. The enzyme was stable over the range $\mathrm{pH} \mathrm{3-7}$ (Fig. 3A). Thermostability was measured by incubating the enzyme solution $(0.15 \mathrm{U} / \mathrm{mL})$ at $\mathrm{pH} 4.0$ and various temperatures for $10 \mathrm{~min}$. After cooling in an ice bath, the residual activity was measured under the standard assay conditions with $0.015 \mathrm{U}$ of enzyme. The purified enzyme retained its original activity on heating below $50^{\circ} \mathrm{C}$ (Fig. 3B).

\section{Effect of various metal ions and chemical reagents on the activity of the enzyme.}

The enzyme activity was assayed with the standard assay method, using $0.02 \mathrm{U}$ of enzyme and $0.5 \mathrm{~mm}$ of metal ions or reagents. The enzyme was completely inactivated by $\mathrm{Hg}^{2+}$ and $\mathrm{SDS}$, but $\mathrm{Ag}^{+}, \mathrm{Sn}^{2+}, \mathrm{Fe}^{3+}$ and $p$-chloromercuribenzoic acid reduced it to $45,15,15$ and $60 \%$ of its original activity, respectively. EDTA and other metal ions $\mathrm{Na}^{+}, \mathrm{K}^{+}, \mathrm{Mn}^{2+}, \mathrm{Al}^{3+}, \mathrm{Fe}^{2+}, \mathrm{Mg}^{2+}, \mathrm{Zn}^{2+}, \mathrm{Ba}^{2+}, \mathrm{Cd}^{2+}$, $\mathrm{Cu}^{2+}, \mathrm{Ni}^{2+}, \mathrm{Co}^{2+}, \mathrm{Ca}^{2+}$ ) tested had no inhibitory effect on the activity of the enzyme. The effects of ethanol and glucose on the enzyme activity were also measured with the standard assay method with $0.02 \mathrm{U}$ of enzyme. Ethanol was added to the reaction mixture at a final concentration of 5,10 , and $20 \%$. In the case of glucose, 100, 200 and $400 \mathrm{~mm}$ of glucose were added to the reaction mixture. The addition of ethanol increased enzyme activity at 5\% ethanol (1.1-fold) and 10\% ethanol (1.05-fold), but had no effect at $20 \%$. In contrast the enzyme activity decreased with increasing glucose concentration. The relative activity was decreased $12 \%$ at $100 \mathrm{mM}, 20 \%$ at $200 \mathrm{mM}$ and $35 \%$ at $400 \mathrm{~mm}$ glucose.

\section{Substrate specificity.}

The purified enzyme was tested for its substrate specificity under the standard assay conditions with $0.035 \mathrm{U}$ of enzyme and a $5 \mathrm{mM}$ concentration of each substrate in the reaction mixture at $\mathrm{pH} 4.0$ and $50^{\circ} \mathrm{C}$ for $15 \mathrm{~min}$ (Table 3). The tests of various substrates (except $p$ NP-compounds) were measured by the Somogyi and Nelson method ${ }^{18,19)}$ with glucose as a standard.

The enzyme has a fairly wide substrate specificity. Among substrates tested, cellobiose, cellotriose, gentiobiose and $p$-nitrophenyl $\beta$-D-glucoside were the most favorable substrates. The enzyme was shown to hydrolyze efficiently oligosaccharides having $\beta-1,2-, \beta-1,3-, \beta-1,4-$ and $\beta$-1,6-glucosidic linkages. The relative rate of hydrolysis of cellooligosaccharides decreased with increasing degree of polymerization. On the other hand, the enzyme had no measurable activity with $p$-nitrophenyl $\beta$-xyloside, $p$-nitrophenyl $\beta$-galactoside and $p$-nitrophenyl $\alpha$-D-glucoside and maltose as substrates.

\section{Preparation of tofu.}

Results are shown in Table 4. The aglycon form of isoflavone in tofu $\mathrm{B}$ with added $\beta$-glucosidase was increased 10-fold and formation of glucosides was decreased. Malonyl (6"-O-malonyl $\beta$-glucoside) and acetyl $(6$ " $O$-acetyl $\beta$-glucoside) were formed at almost the same level.
Table 3. Substrate specificity of the purified enzyme from Aspergillus pulverulentus YM-80.

\begin{tabular}{|c|c|}
\hline Substrate* & $\begin{array}{c}\text { Relative activity }{ }^{* *} \\
(\%)\end{array}$ \\
\hline$p$-Nitrophenyl $\beta$-D-glucoside & 100 \\
\hline$p$-Nitrophenyl $\beta$-D-xyloside & 0 \\
\hline$p$-Nitrophenyl $\beta$-D-galactoside & 0 \\
\hline$p$-Nitrophenyl $\alpha$-D-glucoside & 0 \\
\hline Cellobiose $(\beta-1,4)$ & 125 \\
\hline Cellotriose $(\beta-1,4)$ & 105 \\
\hline Cellotetraose $(\beta-1,4)$ & 92 \\
\hline Cellopentaose $(\beta-1,4)$ & 86 \\
\hline Sophorose $(\beta-1,2)$ & 90 \\
\hline Gentiobiose $(\beta-1,6)$ & 125 \\
\hline Laminaribiose $(\beta-1,3)$ & 84 \\
\hline Maltose $(\alpha-1,4)$ & 0 \\
\hline Helicin & 91 \\
\hline Salicin & 24 \\
\hline Arbutin & 75 \\
\hline Phloridin & 19 \\
\hline Stevioside & trace \\
\hline Esculin & 21 \\
\hline Genistin & 11 \\
\hline Daidzin & 10 \\
\hline
\end{tabular}

${ }^{*}$ Substrate was used at $5 \mathrm{mM}$ in the reaction mixture. ${ }^{* *}$ The activity toward $p$ NP-compounds was determined by measuring the release of $p \mathrm{NP}$, and the relative activity is expressed as the percentages of the activity toward $p$ NPG (Substrate consumption: 10.5\%).

Table 4. Isoflavone contents in tofu.

\begin{tabular}{cccc}
\hline Compound & Soybean & $\begin{array}{c}\text { Tofu A* } \\
(\mathrm{mg} / 100 \mathrm{~g} \text { of soybean) }\end{array}$ & Tofu B** \\
\hline Glucoside & & & \\
Daidzin & 51.8 & 21.2 & 1.8 \\
Glycitin & 28.6 & 11.4 & 0.6 \\
Genistin & 72.0 & 30.9 & 2.3 \\
Malonyl & & & \\
Daidzin & 33.2 & 12.8 & 12.6 \\
Glycitin & 15.2 & 5.9 & 5.4 \\
Genistin & 40.8 & 17.1 & 15.3 \\
Acetyl & & & 0.2 \\
Daidzin & 0.2 & 0.1 & 0.2 \\
Glycitin & 0.3 & 0.2 & 0.7 \\
Genistin & 6.8 & 0.9 & 21.0 \\
Aglycon & & & 8.8 \\
Daidzein & 5.8 & 2.9 & - \\
Glycitein & - & 2.1 & 2.1 \\
Genistein & 4.8 & & \\
\hline
\end{tabular}

${ }^{*}$ Untreated with enzyme. ${ }^{* *}$ Treated with enzyme. Isoflavone contents were defined with the value of $100 \mathrm{~g}$ soybean equivalent.

\section{DISCUSSION}

$\beta$-Glucosidase from Aspergillus pulverulentus YM-80 isolated from soil was highly purified by consecutive column chromatography. This is the first report of $\beta$ glucosidase from A.pulverulentus. A. pulverulentus is well known as the producer of pectinase that is recognized as a food additive, so this strain is acceptable as a producer of food additive enzymes.

Many filamentous fungi have been reported to produce multiple $\beta$-glucosidases ${ }^{20-23)}$ but this fungus produced almost exclusively one single $\beta$-glucosidase from solid culture with wheat bran. The purified $\beta$-glucosidase had a specific activity of $308 \mathrm{U} / \mathrm{mg}$ protein and was homoge- 
neous on SDS-PAGE as well as with isoelectric focusing. The molecular weight of the purified enzyme was 118,000 (by SDS-PAGE) and 240,000 by gel filtration, and is most probably a structural dimer. The molecular weight is close to that of $\beta$-glucosidase from A. sojae. ${ }^{13)}$ The $\mathrm{p} I$ of the purified enzyme is 4.5 , which is close to that of A. oryzae ${ }^{11)}$ but different from that of A. fumigatus (6.0). ${ }^{12)}$ The purified enzyme contained $28.1 \%$ carbohydrate by weight. The $\beta$-glucosidase from a solid culture of $A$. so$j a e^{13)}$ is also reported to have a high carbohydrate content in its enzyme protein $(23.8 \%)$.

The optimum $\mathrm{pH}$ (4.0) of the purified enzyme is very similar to that of $\beta$-glucosidase II from A.tubingensis CBS 643.92, ${ }^{24)}$ but lower than that of other fungal $\beta$ glucosidases such as that from A. niger (5.0) $)^{6}$ or A. japonicus $(5.0) .^{25)}$ The $\mathrm{pH}$-stability $\left(3^{-7}\right)$ of the enzyme is within the range of the $\beta$-glucosidase of A. fumigatus (2$8)^{12)}$ and $A$. niger $(2.5-9.0){ }^{10)}$ The optimum temperature $\left(60^{\circ} \mathrm{C}\right)$ of the purified enzyme is similar to that of $A$. sojae $\left(60^{\circ} \mathrm{C}\right)^{13)}$ but higher than that of A. niger $\left(50^{\circ} \mathrm{C}\right){ }^{6}{ }^{6}$ The thermal stability of this purified $\beta$-glucosidase extended up to $50^{\circ} \mathrm{C}$ at $\mathrm{pH} 4.0$ for $10 \mathrm{~min}$ incubation, almost the same as that from $A$. sojae ${ }^{13)}$ and $A$. niger. ${ }^{6}$ )

The $\beta$-glucosidases from $A$. oryzae $e^{11)}$ and Botrysis cine$r e a^{26)}$ have been reported to have the ability to hydrolyze both $\alpha$ - and $\beta$-glucosides, but this purified enzyme did not hydrolyze $\alpha$-linked disaccharides like maltose. The $\beta$ glucosidases from A. oryzae ${ }^{11)}$ and A. niger CCRC $31494^{27)}$ are reported to hydrolyze $\beta$-linked glucopyranosides and xylopyranosides, but this enzyme acted specifically on $\beta$-linked glucopyranosides. The characteristic of lacking the ability to hydrolyze $\beta$-linked xylopyranosides and $\alpha$-linked saccharides is favorable, because this enzyme will produce fewer effects in foodstuffs with many components.

In general, fungal $\beta$-glucosidases have wide substrate acceptance for $\beta$-linked glucosides. ${ }^{9,11,13,28)}$ This enzyme was also able to hydrolyze a variety of $\beta$-linked disaccharides such as sophorose $(1 \rightarrow 2)$, laminaribiose $(1 \rightarrow 3)$, cellobiose $(1 \rightarrow 4)$ and gentiobiose $(1 \rightarrow 6)$. Thus, the purified enzyme was not limited to only the $\beta$-D- $(1 \rightarrow 4)$ linkage, but could easily hydrolyze $\beta$-D- $(1 \rightarrow 2), \beta-D-(1 \rightarrow 3)$ and $\beta$-D- $(1 \rightarrow 6)$ linkages.

Many $\beta$-glucosidases have been reported to hydrolyze aryl $\beta$-glucosides. As a typical example, the $\beta$-glucosidase from A. phoenicis QM329 $9^{29)}$ is known to hydrolyze several aryl $\beta$-glucosides such as esculin, salicin, phlorizin and arbutin. This purified enzyme also hydrolyzed these aryl $\beta$-glucosides, but the rate of hydrolysis was somewhat different. The purified enzyme easily hydrolyzed $p$ NPG, hellicin, and arbutin, compared with salicin, esculin, phloridin, genistin and daidzin. The difference of hydrolysis rate toward aryl $\beta$-glucosides was caused by inhibition due to the three-dimensional structure or size of aglycons. A. phoenicis is a member of the black Aspergillus genus and taxonomically close to A. pulverulentus.

This enzyme's activity was inhibited by glucose. Competitive inhibition by glucose or substrate is a common characteristic of fungal $\beta$-glucosidases. ${ }^{2,30}$ On the other hand, alcohol enhanced the activity of this enzyme. The activity of $\beta$-glucosidase from A. niger CCRC $31494^{27)}$ was also reported to be enhanced by alcohol. From these results, this enzyme could be useful in wine making to enhance flavor; however glucose slightly inhibits its $\beta$ glucosidase activity.

We have also studied other possible applications of this enzyme. Soybean products have become more and more popular in the world since the U.S. Food and Drug Administration approved the health claim that soy protein reduces the risk of heart disease. In Japan, there are many traditional foods based on soybeans, fermented or not fermented. Recently, isoflavones have been reported to inhibit the growth of cancer, decrease age-related bone loss, and lower blood cholesterol. ${ }^{31-33)}$ Soybeans are also a good source of isoflavones. Isoflavones in soybeans are found mainly as glycosides in unfermented soy foods like tofu. ${ }^{34)}$ Aglycon form isoflavones are absorbed faster than the glycoside form in humans, ${ }^{35)}$ so we have tested the production of aglycon form-rich tofu by this $\beta$-glucosidase. By addition of the $\beta$-glucosidase, the content of the aglycon form of isoflavone in tofu was increased about 10fold and the glucoside form was decreased.

Modified glucosides such as 6 "- $O$-acetyl $\beta$-glucosides and 6 "- $O$-malonyl $\beta$-glucosides were resistant to the enzyme.

We are now studying the kinetic properties of this $\beta$ glucosidase, such as its inhibition by glucose or substrate, and also investigating additional applications such as winemaking.

\section{REFERENCES}

1 ) E.C. Webb: Enzyme Nomenclature: Recommendations of the Nomenclature Committee of the International Union of Biochemistry and Molecular Biology, Academic Press, New York, pp. 346-365 (1992).

2 ) J. Woodward and A. Wiseman: Fungal and other $\beta$-D-glucosidases-their properties and applications. Enzyme Microb. Technol., 4, 73-79 (1982).

3 ) J.P. Harbone, H. Baxter and G.P. Moss (eds.): PART IV Phenolics. in Phytochemical Dictonary: A Handbook of Bioactive Compounds from Plants, 2nd Ed., Taylor and Francis Ltd., London, pp. 359-602 (1999).

4 ) T. Yanai and M. Sato: Isolation and properties of $\beta$-glucosidase produced by Debaryomyces hansenii and its application in winemaking. Am. J. Enol. Vitic., 50, 231-235 (1999).

5 ) J.-H. Moon, N. Watanabe, Y. Ijima, A. Yagi and K. Sakata: cis- and trans-Linalool 3,7-oxides and methyl salicylate glycosides and (Z)-3-hexenyl $\beta$-D-glucopyranoside as aroma precursors from tea leaves for oolong tea. Biosci. Biotechnol. Biochem., 60, 1815-1819 (1996).

6 ) A. Peshin and J.M.S. Mathur: Purification and characterization of $\beta$-glucosidase from Aspergillus niger strain 322. Lett. Appl. Microb., 28, 401-404 (1999).

7 ) J. Lin, B. Pillay and S. Singh: Purification and biochemical characteristics of $\beta$-D-glucosidase from a thermophilic fungus, Thermomyces lanuginosus-SSBP. Biotechnol. Appl. Biochem., 30, 81-87 (1999).

8 ) K.B. Oh, K. Hamada, M. Saito and H.J. Lee: Isolation and properties of an extracellular $\beta$-glucosidase from a filamentous fungus, Cladosporium resinae, isolated from Kerosene. Biosci. Biotechnol. Biochem., 63, 281-287 (1999).

9 ) S.M. Pitson, R.J. Seviour and B.M. McDougall: Purification and characterization of an extracellular $\beta$-glucosidase from the filamentous fungus Acremonium persicinum and its probable role in $\beta$-glucan degradation. Enzyme Microb. Technol., 21, 182-190 (1997).

10) T. Unno, K. Ide, T. Yazaki, Y. Tanaka, T. Nakakuki and 
G. Okada: High recovery purification and some properties of a $\beta$-glucosidase from Aspergillus niger. Biosci. Biotechnol. Biochem., 57, 2172-2173 (1993).

11) C. Riou, J.M. Salmon, M.J. Vallier, Z. Gunata and P. Barre: Purification, characterization, and substrate specifity of a novel highly glucose-tolerant $\beta$-glucosidase from Aspergillus oryzae. Appl. Environ. Microbiol., 64, 3607-3614 (1998).

12) E.A. Ximenes, C.R. Felix and C.J. Ulhoa: Production of cellulases by Aspergillus fumigatus and characterization of one $\beta$ glucosidase. Curr. Microbiol., 32, 119-123 (1996).

13) I. Kimura, N. Yoshioka and S. Tajima: Purification and characterization of a $\beta$-glucosidase with $\beta$-xylosidase activity from Aspergillus sojae. J. Biosci. Bioeng., 87, 538-541 (1999).

14) K.B. Raper and D.I. Fennel: Monographs on "Aspergillus niger Group." in The Genus Aspergillus, Williams and Wilkins Company, Baltimore, Maryland, pp. 293-344 (1965).

15) O. Vesterberg and H. Svensson: Isoelectric fractionation, analysis, and characterization of ampholytes in natural $\mathrm{pH}$ gradients: IV. Further studies on the resolving power in connection with separation of myoglobins. Acta Chem. Scand., 20, 820-834 (1966).

16) J.E. Hodge and B.T. Hofreiter: Determination of reducing sugar and carbohydrates. in Methods in Carbohydrate Chemistry, R.L. Whistler and M.L. Wolfrom, eds., vol. 1., Academic Press, New York, pp. 380-394 (1962).

17) T. Toda, J. Tamura and T. Okuhira: Isoflavone content in commercial soybean foods. FFI J, Jpn., 172, 83-89 (1997).

18) M. Somogyi: Notes on sugar determination. J. Biol. Chem., 195, 19-23 (1952).

19) N. Nelson: Aphotometric adaptation of the Somogyi method for the determination of glucose. J. Biol. Chem., 153, 375-380 (1944).

20) T.M. Wood and S.I. McCrae: Purification and some properties of the extracellular $\beta$-D-glucosidase of the cellulolytic fungus Trichoderma koningii. J. Gen. Microbiol., 128, 2973-2982 (1982).

21) R. Sakamoto, M. Arai and S. Murao: Enzymic properties of three $\beta$-glucosidases from Aspergillus aculeatus No. F-50. Agric. Biol. Chem., 49, 1283-1290 (1985).

22) K.M. Bhat, J.S. Gaikwad and R. Maheshwari: Purification and characterization of an extracellular $\beta$-glucosidase from the thermophilic fungus Sporotrichum thermophile and its influence on cellulase activity. J. Gen. Microbiol., 139, 2825-2832 (1993).

23) M.E. Himmel, W.S. Adney, J.W. Fox, D.J. Mitchell and J.O. Baker: Isolation and characterization of two forms of $\beta$ D-glucosidase from Aspergillus niger. Appl. Biochem. Biotechnol., 39/40, 213-225 (1993).

24) C.H. Decker, J. Visser and P. Schreier: $\beta$-Glucosidase multiplicity from Aspergillus tubingensis CBS 643.92: Purification and characterization of four $\beta$-glucosidases and their differentiation with respect to substrate specificity, glucose inhibition and acid tolerance. Appl. Microb. Biotechnol., 55, 157-163 (2001).

25) A. Sanyal, R.K. Kundu, S. Dube and D.K. Dube: Extracellular cellulolytic enzyme system of Aspergillus japonicus: 2. Purification and characterization of an inducible extracellular $\beta$ glucosidase. Enzyme Microb. Technol., 10, 91-99 (1988).

26) Y. Gueguen, P. Chemardin, A. Arnaud and P. Galzy: Purification and characterization of an intracellular $\beta$-glucosidase from Botrytis cinerea. Enzyme Microb. Technol., 17, 900-906 (1995).

27) T.-R. Yan and C.-L. Lin: Purification and characterization of a glucose-tolerant $\beta$-glucosidase from Aspergillus niger CCRC
31494. Biosci. Biotechnol. Biochem., 61, 965-970 (1997).

28) T. Mega and Y. Matsushima: Comparative studies of three exo- $\beta$-glycosidases of Aspergillus oryzae. J. Biochem., 85, 335-341 (1979).

29) D. Sternbeng, P. Vijayakumar and E.T. Reese: $\beta$-Glucosidase: Microbial production and effect on enzyme hydrolysis of cellulose. Can. J. Microbiol., 23, 139-147 (1976).

30) H.H. Yeoh, T.K. Tan, S.L. Chua and G. Lim: Properties of $\beta$ glucosidase purified from Aspergillus niger. MIRCEN J., 4, 425-430 (1988).

31) S.M. Potter, J.A. Baum, H. Teng, R.I. Stillman and F.N. Shay: Soy protein and isoflavones: Their effects on blood lipids and bone density in postmenopausal women. Am. J. Clin. Nutr., 68, 1375S-1379S (1998).

32) J.J.B. Anderson and S.C. Garner: The effects of phytoestrogens and bone. Nutr. Res., 17, 1617-1632 (1997).

33) M.J. Messina, V. Persky, K.D.R. Setchell and S. Barnes: Soy intake and cancer risk: A review of the in vitro and in vivo date. Nutr. Cancer., 21, 113-131 (1994).

34) H.J. Wang and P.A. Murphy: Isoflavone content in commercial soybean foods. J. Agric. Food Chem., 42, 1666-1673 (1994).

35) T. Izumi, M.K. Piskula, S. Osawa, A. Obata, K. Tobe, M. Saito, S. Kataoka, Y. Kubota and M. Kikuchi: Soy isoflavone aglycones are absorbed faster and in higher amounts than their glucosides in humans. J. Nutr., 130, 1695-1699 (2000).

\section{Aspergillus pulverulentus YM-80 の産生する $\beta$-グルコシダーゼの精製と諸性質およびその応用}

間瀬民生，森 茂治，横江正明

天野エンザイム株式会社岐阜研究所

（509-0108 各務原市須衛町 4-179-35）

食品加工に適した, 基質特異性の広い $\beta$-グルコシダー ゼを産生する菌として, 土㙵から Aspergillus pulverulentus YM-80を分離した。本菌株の産生する $\beta$-グルコシダーゼ を, 固体培養後の抽出粗酵素液の硫安塩析, DEAEToyopearl 650M, Butyl-Toyopearl 650M および Sephacryl S-200 クロマトグラフィーにより，精製収率 $15 \%$ で電気 泳動的に単一にまで精製した。精製酵素は比活性 $308 \mathrm{U} /$

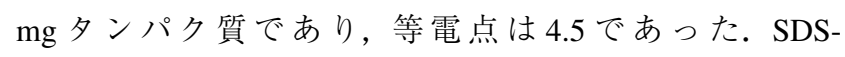
PAGEによる分子量測定では 118,000 , ゲルろ過では 240,000 であった. 最適 $\mathrm{pH}$ は 4.0, 最適温度は $60^{\circ} \mathrm{C}, \mathrm{pH}$

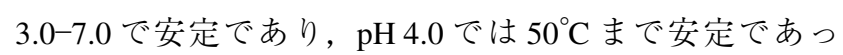

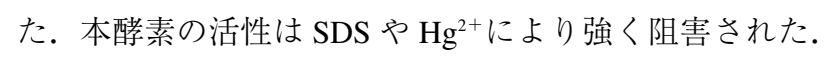
本酵素はセロビオースやゲンチオビオース, ソホロース 等の $\beta$ 結合を持つオリゴ糖に広い特異性を示したが，マル トースなどの $\alpha$ 結合型には作用しなかった（Table 3). 本 酵素は豆腐加工において, 大豆イソフラボンのグルコシ ド配糖体のアグリコン化に有用であったが, アセチル化 やマロニル化されたグルコシド配糖体のアグリコン化は ほとんど認められなかった。 